\title{
Carbon stock estimation of mangrove forest in Sulaman Lake Forest Reserve, Sabah, Malaysia
}

\author{
NURUL SYAKILAH SUHAILI, JIM LIEW JUN FEI, FAUZAN WAJDI SHA'ARI, \\ MUHAMMAD IZZUDDIN IDRIS, SYAHRIR MHD HATTA, JULIUS KODOH, NORMAH AWANG BESAR \\ Forestry Complex, Faculty of Science and Natural Resources, Universiti Malaysia Sabah. Jl. UMS, 88400 Kota Kinabalu, Sabah, Malaysia. \\ Tel.: +60-88-320000, `email: normabr@ums.edu.my
}

Manuscript received: 15 October 2020. Revision accepted: 18 November 2020.

\begin{abstract}
Suhaili NS, Fei JLJ, Sha'ari FW, Idris MI, Hatta SH, Kodoh J, Besar NA. 2020. Carbon stock estimation of Sulaman Lake Forest Reserve in Sabah, Malaysia. Biodiversitas 21: 5657-5664. Mangrove forest has a significant role in sequestering carbon gases from the atmosphere but there are lesser literature has been made on it. This research was conducted to quantify the aboveground, belowground and soil carbon stock in Sulaman Lake Forest Reserve, Sabah, Malaysia. Nine transect lines with $125 \mathrm{~m}$ length were established and a circle with $7 \mathrm{~m}$ radius was set in every $25 \mathrm{~m}$. Forest inventory was done to get the diameter breast height of standing trees and soil sampling with four different depths $(0-15 \mathrm{~cm}, 15-30 \mathrm{~cm}, 30-50 \mathrm{~cm}$ and $50-100 \mathrm{~cm})$ were taken for soil analysis and bulk density. Allometric equation was used to calculate aboveground and belowground biomass then its carbon stock was estimated as $50 \%$ from its total biomass. The result shows the total carbon stock in the study area was $441.72 \mathrm{Mg} \mathrm{C} \mathrm{ha}^{-1}$, and soil has the highest value of carbon stock $\left(351.98 \pm 11.73 \mathrm{Mg} \mathrm{Cha}^{-1}\right)$ followed by aboveground carbon $\left(67.30 \pm 20.55 \mathrm{Mg} \mathrm{C}^{-1}\right)$ and belowground carbon $(22.44 \pm$ $0.17 \mathrm{Mg} \mathrm{C} \mathrm{ha}^{-1}$ ). This study found that soil carbon stock made up almost $80 \%$ of the total carbon stock in the mangrove forest. This ecosystem also shows a higher value of carbon stock compared to other locations hence emphasized the importance of prioritizing a mangrove forest in any climate mitigation efforts.
\end{abstract}

Keywords: Aboveground, belowground, carbon stock, mangrove forest, soil carbon

\section{INTRODUCTION}

The Mangrove forest is a type of forest that has a unique ecosystem in which the plant community that lives inside has its very own way to adapt and survive the abnormal living condition for a plant to grow such high salinity, extreme tides, and muddy soils (Giri et al. 2011). It was estimated that the world's total mangrove areas are ranging from 14-15 million ha (1990-2020 data) with Asia holds the biggest number of it which approximately 6.8 million ha (FAO 2020; Kauffman and Donato 2012) and was estimated to have an economic value from US\$3624.98 to US \$26734.61/ha/year (Rizal et al. 2018). This economic value comes from the ecosystem services that a mangrove could provide such as forest timber production and carbon credit program (Hemati et al. 2014). Malaysia's mangrove constitutes approximately 537,686 ha in area and Sabah covered more than half of the total area with 364,100 ha. Meanwhile, the mangroves in Sarawak and Peninsular Malaysia is accounted for 132,000 ha $(23 \%)$ and 104,181 ha $(18 \%)$ respectively (Olaniyi et al. 2012; Marzuki 2019; Tangah et al. 2020).

Donato et al. (2011) reported mangrove forests are three to five times more effective in storing carbon compared to other types of forest and almost $70 \%$ to $90 \%$ of it was stored in the soil (Hance 2011). These values show how important it is to do an accurate measurement of the mangrove forest carbon storage. Though the carbon pools inside the mangrove forest have great ability to store carbon for a long time, the information regarding this matter is still lacking especially in the belowground carbon pools. Despite all the important services that a mangrove forest could provide, the rate of deforestation and degradation is still at alarming rate. Bryan-Brown (2020) reported Indonesia, Malaysia, and Myanmar showing a continuing number of mangrove losses with $0.26 \%, 0.41 \%$ and $0.70 \%$ respectively. This problem comes from unsustainable anthropogenic activities that were done in mangrove areas such as conversion into aquaculture sites, timber harvesting and shrimp farming (Goessens et al. 2014). These treats obviously could give a bad impact on the natural function of the mangrove forest especially in combating the current issue which is mitigating climate change. When destruction or land changes happen, the carbon pools inside the mangrove ecosystem will be reduced and this could affect the capability of forest to capture and store carbon. Any kind of changes or losses that happen inside mangrove forests also could cause the forest to become the main source of atmospheric carbon emissions (Kauffman et al. 2011). A deeper investigation on the mangrove ecosystem carbon stocks and the impact of human activities on it is much needed so a better plan and strategies can be implemented to protect the forest. The conservation of mangrove forests is essential in offsetting carbon emission and climate change.

Several publications that have been made on the Malaysian's mangrove are carbon stock evaluation in mangrove forest at Peninsular Malaysia (Hong et al. 
2017), soil carbon storage in Sarawak's mangrove (Chandra et al. 2015), and soil chemical properties by Rambok et al. (2010). Although Sabah covered more than half of the total mangrove in Malaysia, not much information could be found about its value as global carbon (C) stocks. Therefore, it is very crucial to fill this gap so a better understanding of the function and contribution of mangrove forests can be achieved. The main objective of this research is to quantify the main carbon pools in mangroves which are the living vegetation and soil carbon. This study would provide feasible data for future management planning and hopefully the realization for Reducing Emissions from Deforestation and Forest Degradation, and Enhancing Forest Carbon Stocks in Developing Country (REDD+) programs.

\section{MATERIALS AND METHODS}

\section{Study area}

This study was conducted at Sulaman Lake Forest Reserved, Sabah, Malaysia. The Sulaman Lake Forest Reserved is a mangrove forest that can be found at the west coast division of Sabah, Malaysia and is under Kota Kinabalu forestry district. The total area of this site is approximately 2635 hectares and was gazetted as a class V forest reserve under the Forest Enactment 1968. Under this regulation, most of the mangrove forest in Sabah are gazetted as Mangrove Forest Reserve (Class V), Protection Forests (Class I), and Virgin Jungle Forest Reserve (Class VI) (Tangah et al. 2020). This classification is done as one of the efforts for mangrove forest conservation in Sabah. A small scale of commercially harvesting activities are allowed in a Class V forest reserve and it is limited only for domestic consumption. Some of the products that usually being harvested from this forest are charcoal and fuelwood. Meanwhile, any kind of harvesting is prohibited in a Class VI forest reserve as the main purpose of the classification is to conserve and protect the forest. The only activities that allowed to be done inside a Class VI forest are research, education, and gene bank (Tangah and Chung 2011). The elevation is 18 meters above the sea and the coordinate is in between $\mathrm{N} 6^{0} 15^{\prime} 15.48^{\prime}$ ' latitude and E $116^{\circ} 16^{\prime}$ '55.19" longitude (Figure 1). The common mangrove species in this site are Rhizophora apiculata, Rhizophora mucronata, Avicennia alba, and Ceriops decandra.

\section{Procedures \\ Experimental design}

The carbon stocks that have been measured in this study are the standing trees for both above and belowground carbon and the soil carbon. A non-destructive method was implemented to estimate the aboveground data and soil sampling was done to get the belowground data. A transect line method was used in this study and this method is applied based on the protocol book that has been published by Kauffman et al. (2011). The field data collections were done on August-October 2016 and August 2017. There were 9 transect lines have been established randomly across the study site and within each transect, 5 subplots were established to get the replicate of the samples. The length of each established transect line established is 125 meters and each subplot was built in a circle. The circle is 7 meters in radius and the distance between each subplot is 25 meters. All standing trees with a diameter breast height (DBH) more than $5 \mathrm{~cm}$ that can be found within the subplots were measured for aboveground biomass and soil sampling was done at an accessible random point within each subplot for soil carbon stock.

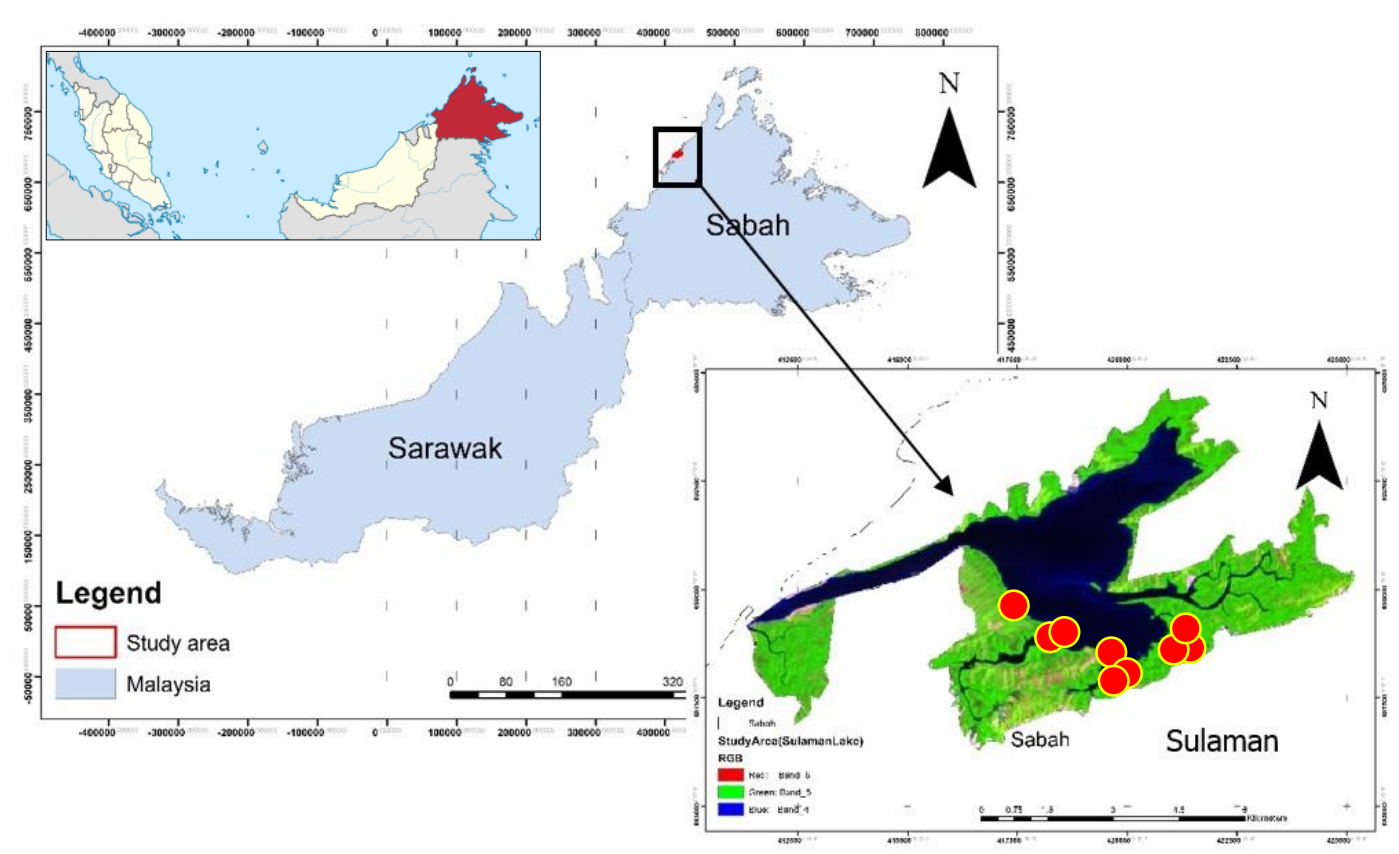

Figure 1. Location of Sulaman Lake Forest Reserve, Sabah, Malaysia (N 6 ${ }^{0} 15^{\prime} 15.48^{\prime \prime}$, E $\left.116^{0} 16^{\prime} 55.19^{\prime \prime}\right)$, which can be found on the west coast division of Sabah, Malaysia and is facing the South China Sea (Tangah et al. 2020; Wong et al. 2020). The triangles represent nine (9) established transects inside the study area 


\section{Field data collection}

Forest inventory was done to get the diameter breast height $(\mathrm{DBH})$ of both standing live and dead trees inside the transect lines. All trees with DBH greater than $5 \mathrm{~cm}$ were measured in the $7 \mathrm{~m}$ radius and for trees with stem diameters between $0.5 \mathrm{~cm}$ and $5 \mathrm{~cm}$, only those within $2 \mathrm{~m}$ radius from the center of circle were measured. Typically, tree stem diameter will be recorded 1.37 meter above the ground but as some species of mangrove have stilt types of roots, the measurement was taken on the highest roots (Komiyama et al. 2005; Kauffman and Donato 2012). The decaying status of standing dead trees also was recorded and categorized as 3 classes which are Class 1 (dead tree that still have small branches and twigs attached with the stem), Class 2 (dead tree that has lesser twigs or branches attached with the stem) and Class 3 (dead tree with a standing stem only).

Soil sampling was taken by using sampling tools such as PVC pipe, scope, and shovels. The PVC pipe was used as an auger to get the mixed soil samples for soil physicochemical properties. A bulk density ring with the volume $98.125 \mathrm{~cm}^{3}$ was used to collect the undisturbed soil sample for the measurement of bulk density. All samples were taken at four depths: $0-15 \mathrm{~cm}, 15-30 \mathrm{~cm}, 30-50 \mathrm{~cm}$, and $50-100 \mathrm{~cm}$.

\section{Data analysis}

Soil analysis

All soil samples were analyzed for their physicochemical properties after being air-dried at room temperature and sieved using a $2 \mathrm{~mm}$ soil siever. The soil physical properties were soil moisture content, soil texture, and soil bulk density, while for chemical properties were soil $\mathrm{pH}$, soil salinity, soil cation exchange capacity (CEC), soil nutrient content and soil carbon concentration. Soil moisture content was determined by using Gravimetric method in which the soil water loss was calculated after being dried at $105^{\circ} \mathrm{C}$ for 24 hours (Shukla et al. 2014) meanwhile soil bulk density is expressed as the ratio of the dry mass of soil over its volume (Han et al. 2016). The percentage of silt, clay, and sand was calculated using Pipette method and the same values were used to determine the soil texture by referring it to USDA Soil Classification Triangle.

Soil $\mathrm{pH}$ value was measured using soil-distilled water ratio $(1: 2.5)$ method and a $\mathrm{pH}$ meter while soil salinity was measured using a portable refractometer. The determination of soil organic matter was done by measuring the dry weight of soil after being ignite at $500{ }^{\circ} \mathrm{C}$ for 24 hours (loss-on-ignition method). Total cation exchange capacity (CEC) in soil was measured by summing the exchangeable cation which is base cations (calcium, magnesium, potassium and sodium) and acid cations (hydrogen and aluminum) (Culman et al. 2019). All the elements (except hydrogen) were extracted by digesting the soil using aqua regia then analyzed using Inductively Couple Plasma-Optical Emission Spectrometry (ICP-OES) machine. Soil nutrient availability also was analyzed using the same method. A Vario EL CHNS (carbonhydrogen-nitrogen-sulfur) auto analyzer was used to get the concentration of carbon, hydrogen, nitrogen and sulfur.

\section{Aboveground and belowground biomass analysis}

There are several other equations that were established to calculate biomass of mangrove trees, but as there is not enough information on the distribution of species in the study site, the choices of allometric equations are limited (Wong et al. 2020). An allometric equation for Rhizophora spp that was generated by Fromard et al. (1998) was used to calculate the aboveground biomass as the dominant species for main mangrove zone in Sabah is Rhizophora (Tangah et al. 2020). The equation is $\mathrm{W}=0.128 \mathrm{DBH}^{2.60}$ where it only uses the trees diameter at breast height $(\mathrm{DBH})$ as its parameter. This allometric equation has-8.44 to $+6.81 \%$ of relative error compared to other equations such Clough and Scott (1989) with-9.84 to $+10.3 \%$ and Ong et al. (2004) with +6.81 to $10.8 \%$ (Komiyama et al. 2008). The result for aboveground biomass then was converted into aboveground carbon by using the 0.5 conversion factor in respect of the assumption of standing trees carbon stock is $50 \%$ from its biomass (Houghton and Hackler. 2001). The biomass for roots was calculated by using the 3:1 (AGB: BGB) biomass comparison ratio developed by Kusmana et al. (2018) and its carbon too was estimated as $50 \%$ from its biomass.

\section{Soil carbon stock and total carbon stock}

All undisturbed soil samples that were collected from four different depths were analyzed for their bulk density and carbon concentration. The values then were used as the parameters to calculate the soil carbon stock. The soil carbon stock ( $\mathrm{Mg} \mathrm{C} \mathrm{ha-1)}$ per sampled depth interval was calculated using the equation shown below (Kauffman and Donato 2012) and the total soil carbon stock was calculated by summing all the carbon stock for each soil depth;

Soil carbon $\left(\mathrm{Mg} \mathrm{ha}^{-1}\right)=$ Bulk density $\left(\mathrm{g} \mathrm{cm}^{-3}\right) \times$ Soil Depth Interval $(\mathrm{cm}) \mathrm{x}$ Carbon concentration $(\% \mathrm{C})$

The total ecosystem carbon pools in Sulaman Lake Forest Reserved were estimated by summing all the main carbon pools that have been measured which are the aboveground (living vegetation) and belowground (roots) and soil carbon pools. The total value of ecosystem carbon stock then was converted into its carbon dioxide equivalents $\left(\mathrm{CO}_{2} \mathrm{e}\right)$ to see the potential value of study site in emitting and absorbing carbon dioxide to and from the atmosphere (Kauffman and Donato 2012; Hong et al. 2017).

\section{RESULTS AND DISCUSSION}

\section{Soil physicochemical properties}

Soil properties such nutrients content, organic matter, and salinity are the key factors that could determine the species composition and structure in a mangrove forest (Hossain and Nuruddin 2016). The soil physical properties (bulk density, moisture content, clay, silt, and sand) and soil chemical properties ( $\mathrm{pH}$, salinity, carbon concentration, and cation exchange capacity) of Sulaman Lake Forest Reserve are shown in Tables 1 and 2.

Both physical and chemical properties of soil were used 
to indicate soil fertility (Rambok et al. 2010). Data obtained show soil bulk density and moisture content did not vary largely throughout the soil depth. The range for both parameters are $0.67 \mathrm{~g} \mathrm{~cm}^{-1}$ to $0.74 \mathrm{~g} \mathrm{~cm}^{-1}$ and $18.46 \%$ to $19.58 \%$ respectively. Sand has the highest percentage among the particles of soil texture with the range of $61.62 \%$ to $54.57 \%$ and silt has the lowest percentage with range of $7.55 \%$ to $12.88 \%$. The soil texture in Sulaman Lake Forest Reserve is sandy clay loam and it was calculated based on the percentage of clay, silt, and sand. The presence of high percentage of sand in soil caused the soil to have high porosity. Soil with high porosity tends to have low bulk density and high water holding capacity.

The range of $\mathrm{pH}$ is from 5.11 to 5.71 thus shows the soil is acidic. The mean is decreased as the depth increased. Soil salinity did not have huge difference throughout the depth with the highest value of 8.9 at $50-100 \mathrm{~cm}$ and lowest 8.3 at $30-50 \mathrm{~cm}$. The mean for soil organic matter ranged from $14.91 \%$ to $18.55 \%$. This high value of soil organic matter caused the soil to have a darker color and also explain the low value of bulk density (Rambok et al. 2010). Analysis of the important elements in the soil shows $\mathrm{Ca}$ and $\mathrm{Na}$ were dominant elements with the range $7.17 \mathrm{meq} / 100 \mathrm{~g}$ to $26.70 \mathrm{meq} / 100 \mathrm{~g}$ and $2.42 \mathrm{meq} / 100 \mathrm{~g}$ to $3.67 \mathrm{meq} / 100 \mathrm{~g}$ respectively. $\mathrm{H}$ and $\mathrm{Mg}$ have the lowest mean range compared to the others ( $\mathrm{Al}$ andK) with lowest value $1.02 \mathrm{meq} / 100 \mathrm{~g}$ and $0.81 \mathrm{meq} / 100 \mathrm{~g}$ and highest value which are $2.15 \mathrm{meq} / 100 \mathrm{~g}$ and $1.75 \mathrm{meq} / 100 \mathrm{~g}$ respectively. The high number of calcium helps in reducing soil salinity and this is important as a high salinity could stunt the tree growth (Hemati et al. 2014). Soil Cation Exchange Capacity (CEC) is increasing with the depth with the lowest value $14.12 \mathrm{meq} / 100 \mathrm{~g}$ at $15-30 \mathrm{~cm}$ and highest value $35.82 \mathrm{meq} / 100 \mathrm{~g}$ at $30-50 \mathrm{~cm}$. Table 3 shows potassium has the highest mean range among the nutrient elements and followed by sulfur $(0.74 \mathrm{ppm}$ to $1.29 \mathrm{ppm})$, nitrogen $(0.80$ ppm to $1.04 \mathrm{ppm})$, and the lowest is phosphorus $(0.10 \mathrm{ppm}$ to $0.85 \mathrm{ppm})$. The result also shows the carbon concentration and carbon-nitrogen ratio did not vary throughout the depths.

\begin{abstract}
Aboveground and belowground biomass
Figure 2 shows the aboveground and belowground biomass for both standing living trees and dead living trees in Sulaman Lake Forest Reserve. The aboveground tree biomass has a greater value compared to the belowground biomass and this is because the roots continuously exposed to the harsh environment of mangroves such as high salinity and highwater table (Kusmana et al. 2018). This study found the aboveground biomass for standing trees in Sulaman Lake Forest Reserve is $134.59 \mathrm{Mg} \mathrm{ha}^{-1}$ and it is slightly higher compared to aboveground biomass found in the dominant species (Rhizophora apiculate) mangrove forest that was measured by Chandra et al. (2011) at AwatAwat mangrove forest, Sarawak, Malaysia which is 116.79 $\mathrm{Mg} \mathrm{ha}{ }^{-1}$. The same paper also mentioned that a species dominant types of forest has higher aboveground biomass values compared to a mixed species (Rhizophora apiculate, Rhizophora mucronata, Ceriops tagal mangrove forest which is $115.56 \mathrm{Mg} \mathrm{ha}^{-1}$.
\end{abstract}

Table 1.The physical properties of soil in Sulaman Lake Forest Reserve, Sabah, Malaysia

\begin{tabular}{lcccccc}
\hline $\begin{array}{c}\text { Soil depth } \\
(\mathbf{c m})\end{array}$ & $\begin{array}{c}\text { Bulk density } \\
(\mathbf{g} \text { cm-1) }\end{array}$ & $\begin{array}{c}\text { Moisture content } \\
(\boldsymbol{\%})\end{array}$ & Sand $(\boldsymbol{\%})$ & Silt $(\boldsymbol{\%})$ & Clay $(\boldsymbol{\%})$ & Texture \\
\hline $0-15$ & $0.74 \pm 0.08$ & $18.46 \pm 2.23$ & $61.62 \pm 5.13$ & $12.88 \pm 2.59$ & $23.81 \pm 3.04$ & Sandy clay loam \\
$15-30$ & $0.67 \pm 0.08$ & $19.58 \pm 2.03$ & $58.85 \pm 6.23$ & $10.37 \pm 3.74$ & $27.50 \pm 3.73$ & Sandy clay loam \\
$30-50$ & $0.70 \pm 0.09$ & $19.73 \pm 1.94$ & $59.70 \pm 6.70$ & $7.55 \pm 1.26$ & $29.88 \pm 5.41$ & Sandy clay loam \\
$50-100$ & $0.72 \pm 0.09$ & $19.22 \pm 1.79$ & $54.57 \pm 8.88$ & $11.96 \pm 3.47$ & $32.96 \pm 6.60$ & Sandy clay loam \\
\hline
\end{tabular}

Table 2.The chemical properties of soil in Sulaman Lake Forest Reserve, Sabah, Malaysia

\begin{tabular}{|c|c|c|c|c|c|c|c|c|c|c|}
\hline \multirow{2}{*}{$\begin{array}{c}\text { Soil } \\
\text { depth } \\
\text { (cm) }\end{array}$} & \multirow{2}{*}{ pH $(1: 2.5)$} & \multirow{2}{*}{ Salinity } & \multirow{2}{*}{$\begin{array}{c}\text { Soil organic } \\
\text { matter }(\%)\end{array}$} & \multicolumn{2}{|c|}{$\begin{array}{l}\text { Acid cations } \\
\text { (meq/100g) }\end{array}$} & \multicolumn{4}{|c|}{ Base cations (meq/100g) } & \multirow{2}{*}{$\begin{array}{c}\text { CEC } \\
(\mathrm{meq} / 100 \mathrm{~g})\end{array}$} \\
\hline & & & & $\mathbf{A l}^{3+}$ & $\mathbf{H}^{+}$ & $\mathrm{Mg}^{2+}$ & $\mathrm{Ca}^{2+}$ & $\mathbf{N a}^{+}$ & $\mathbf{K}^{+}$ & \\
\hline $0-15$ & $5.71 \pm 0.25$ & $8.5 \pm 1.9$ & & $1.35 \pm 0.4$ & $1.02 \pm 0.22$ & $81 \pm 0.25$ & $0 \pm 5.04$ & $.91 \pm 0.84$ & $0.92 \pm 0.36$ & \\
\hline $15-30$ & $5.47 \pm 0.22$ & $8.7 \pm 1.8$ & $17.90 \pm 2.48$ & $1.82 \pm 0.53$ & $1.22 \pm 0.25$ & $0.69 \pm 0.12$ & $7.17 \pm 3.87$ & $2.42 \pm 0.42$ & $0.80 \pm 0.21$ & 5.00 \\
\hline $30-50$ & $5.18 \pm 0.19$ & $8.3 \pm 2.3$ & $18.55 \pm 2.55$ & $1.86 \pm 0.79$ & $1.25 \pm 0.27$ & $0.92 \pm 0.35$ & $26.70 \pm 14.54$ & $3.67 \pm 1.35$ & $1.42 \pm 0.62$ & $35.82 \pm 17.66$ \\
\hline $50-100$ & $5.11 \pm 0.15$ & $8.9 \pm 2.2$ & $14.91 \pm 2.57$ & $2.15 \pm 0.48$ & $1.27 \pm 0.29$ & $0.95 \pm 0.19$ & $18.65 \pm 7.22$ & $3.19 \pm 0.68$ & $1.75 \pm 0.59$ & $27.96 \pm 8.77$ \\
\hline
\end{tabular}

Table 3. Soil nutrient contents in Sulaman Lake Forest Reserve, Sabah, Malaysia

\begin{tabular}{lcccccc}
\hline $\begin{array}{c}\text { Soil depth } \\
(\mathbf{c m})\end{array}$ & Carbon $(\boldsymbol{\%})$ & Total N $(\boldsymbol{\%})$ & $\mathbf{P}(\mathbf{p p m})$ & K $(\mathbf{p p m})$ & S $(\boldsymbol{\%})$ & C:N ratio \\
\hline $0-15$ & $5.46 \pm 1.08$ & $0.80 \pm 0.24$ & $0.10 \pm 0.02$ & $0.92 \pm 0.36$ & $0.74 \pm 0.14$ & $21.46 \pm 1.91$ \\
$15-30$ & $6.37 \pm 1.19$ & $1.04 \pm 0.34$ & $0.52 \pm 0.30$ & $0.80 \pm 0.21$ & $1.13 \pm 0.21$ & $23.28 \pm 1.88$ \\
$30-50$ & $6.15 \pm 1.19$ & $1.03 \pm 0.33$ & $0.12 \pm 0.02$ & $1.42 \pm 0.62$ & $1.24 \pm 0.23$ & $22.63 \pm 2.61$ \\
$50-100$ & $6.47 \pm 1.37$ & $1.03 \pm 0.32$ & $0.85 \pm 0.69$ & $1.75 \pm 0.59$ & $1.29 \pm 0.26$ & $22.47 \pm 3.73$ \\
\hline
\end{tabular}




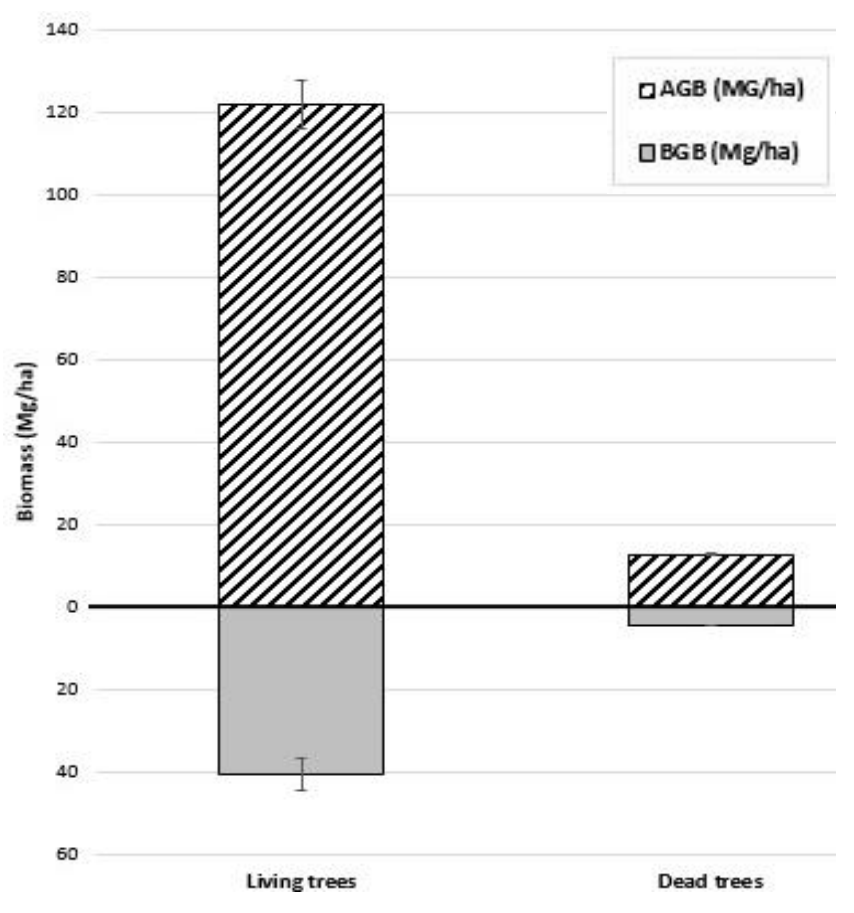

Figure 2. Aboveground and belowground biomass for standing living and dead trees in Sulaman Lake Forest Reserve, Sabah, Malaysia

The recorded number of aboveground biomass in these study area, however, are smaller compared to the aboveground biomass that was reported in an undisturbed mangrove forest at Kuala Selangor Nature Park, Peninsular Malaysia which is $305.03 \mathrm{Mg} \mathrm{ha}^{-1}$ (Hemati et al. 2015). These variations in values depended on the composition of species in the forest and its ecological environment (Komiyama et al. 2008; Chandra et al. 2011). Sulaman Lake Forest Reserve has a similar environment with the Awat-Awat mangrove forest which is both were located near the village and mangrove was dominated by a Rhizophora species (Chandra et al. 2015). Meanwhile, the Kuala Selangor Nature Park is a mangrove forest managed by a Non-Government Organization (NGO) called the Malaysian Nature Society. The restriction to access the Kuala Selangor Nature Park makes it hard for anybody to do any kind of human activities there so most of the area is still undisturbed and this site has more Avicennia and Bruguiera species (Hemati et al. 2015).

There are lesser literature could be found on belowground biomass in mangrove compared to aboveground biomass as it includes an intensive labor work and energy, other than the difficulty to get the sample itself (Njana et al. 2015; Adame et al. 2017). Hossain et al. (2008) in their study at Kuala Selangor Nature Park, Malaysia found that the roots biomass in that mangrove forest is $0.4924 \mathrm{Mg} \mathrm{ha}^{-1}$ meanwhile Komiyama et al. (2000) compiled some studies that have been made on belowground biomass by some mangrove species which
17.4 $\mathrm{Mg} \mathrm{ha}^{-1}$ for Rhizophora forest, 147.3-160.3 $\mathrm{Mg} \mathrm{ha}^{-1}$ for Avicennia forests and $32.4 \mathrm{Mg} \mathrm{ha}^{-1}$ for Sonneratia forest. Our study found a bigger value compared to in the Kuala Selangor Nature Park which is $44.86 \mathrm{Mg} \mathrm{ha}^{-1}$ but is smaller than the study that was mentioned by Komiyama et al. (2000). Some of the reason that might be caused the differences in belowground biomass value is the anoxic environment in the study area, forest structure and the excavation procedures that was applied during measurement (Hemati et al. 2014; Njana et al. 2015). According to Adame et al. (2017), roots biomass are varied among species and usually increases by the forest age. As mentioned above, different types of mangrove species show different value of belowground biomass and it was also recorded that a replanted mangrove forest (Rhizophora apiculata) has $23.1 \mathrm{Mg} \mathrm{ha}^{-1}$ of belowground biomass at 5 years old and $35.6 \mathrm{Mg} \mathrm{ha}^{-1}$ at 25 years old (Alongi and Dixon 2000).

\section{Aboveground carbon stock, belowground carbon stock, soil carbon, and total carbon stock}

In this study, the aboveground and belowground carbon stock was estimated $50 \%$ from its aboveground biomass (Pearson et al. 2007) and soil carbon stock was calculated using equation that has been modified by Kauffman and Donato (2012). Our study found soil has the highest value of carbon stock which is $351.98 \pm 11.73 \mathrm{Mg} \mathrm{C} \mathrm{ha}{ }^{-1}$ followed by aboveground carbon for living trees with 60.86 $\pm 5.74 \mathrm{Mg} \mathrm{C} \mathrm{ha}^{-1}$ and belowground carbon for living trees with $20.29 \pm 1.91 \mathrm{Mg} \mathrm{C} \mathrm{ha}^{-1}$. Meanwhile, both aboveground and belowground carbon for dead trees has the lowest value of carbon stock which are $6.44 \pm 0.17 \mathrm{Mg}$ $\mathrm{ha}^{-1}$ and $2.15 \mathrm{Mg} \mathrm{C} \mathrm{ha}^{-1}$ respectively. The total ecosystem carbon stock in Sulaman Lake Forest Reserved is 441.72 $\mathrm{Mg} \mathrm{C} \mathrm{ha-1} \mathrm{and} \mathrm{after} \mathrm{being} \mathrm{converted} \mathrm{into} \mathrm{carbon} \mathrm{dioxide}$ equivalents (multiplying total ecosystem carbon stock with 3.67), it shows that Sulaman Lake Forest Reserved has the potential to emit and absorb as much as $1621.11 \mathrm{Mg} \mathrm{C}^{-1}$ to and from the atmosphere (Kauffman and Donato 2012; Hong et al. 2017). Martuti et al. (2017) in their study at Semarang, Indonesia illustrate the positive correlation between the total carbon stock and the carbon dioxide absorption of a mangrove forest hence explaining the value of carbon dioxide equivalent in Table 4, which are increasing along with the value of total ecosystem carbon stock.

Table 4 also shows the comparison of aboveground, belowground, and soil carbon stock of mangrove forest from various studies. In most locations, there is a clear distinction of percentage between the living vegetation carbon pools with soil carbon pools. Soil carbon alone could be made up from $44 \%$ to $80 \%$ of the total ecosystem carbon stock meanwhile belowground carbon pools have the least amount of carbon stock percentage which range from $2 \%$ to $22 \%$. This relatively high soil carbon stock was contributed by the high concentration of carbon in soil and bulk density (Kauffman et al. 2011). 
Table 4. Comparison of aboveground carbon, belowground carbon, and soil carbon stock with other studies

\begin{tabular}{|c|c|c|c|c|c|c|}
\hline Location & $\begin{array}{l}\text { Aboveground } \\
\text { carbon } \\
\left(\mathrm{Mg} \mathrm{C} \mathrm{ha}^{-1}\right)\end{array}$ & $\begin{array}{l}\text { Belowground } \\
\text { carbon } \\
\left(\mathrm{Mg} \mathrm{C} \mathrm{ha}^{-1}\right)\end{array}$ & $\begin{array}{l}\text { Soil carbon } \\
\left(\mathrm{Mg} \mathrm{C} \mathrm{ha-1)}^{-1}\right)\end{array}$ & $\begin{array}{l}\text { Total ecosystem } \\
\text { carbon stock } \\
\left(\mathrm{Mg} \mathrm{C} \mathrm{ha}^{-1}\right)\end{array}$ & $\begin{array}{l}\mathrm{CO}_{2} \\
\text { equivalent } \\
\text { (Mg C ha-1) }\end{array}$ & Reference \\
\hline Republic of Yap, Micronesia & $116.7(26 \%)$ & $100.0(22 \%)$ & $237.2(52 \%)$ & 453.9 & 1665.81 & Kauffman et al. (2011) \\
\hline $\begin{array}{l}\text { Sumatra, Sulawesi, Java, } \\
\text { Kalimantan, Papua and Bali, } \\
\text { Indonesia }\end{array}$ & $191.2(20 \%)$ & $21.1(2 \%)$ & $761.3(78 \%)$ & 973.6 & 3573.11 & Alongi et al. (2016) \\
\hline Peninsular Malaysia, Malaysia & $48.17(32 \%)$ & $13.12(8 \%)$ & $90.11(60 \%)$ & 151.4 & 555.64 & Hong et al. (2017) \\
\hline Cotabato City, Philippines & $188.38(38 \%)$ & $66.23(14 \%)$ & $218.03(44 \%)$ & 490.69 & 1800.83 & Dimalen and Rojo (2019) \\
\hline Sabah, Malaysia & $67.30(15 \%)$ & $22.44(5 \%)$ & $351.98(80 \%)$ & 441.72 & 1621.11 & Present study \\
\hline
\end{tabular}

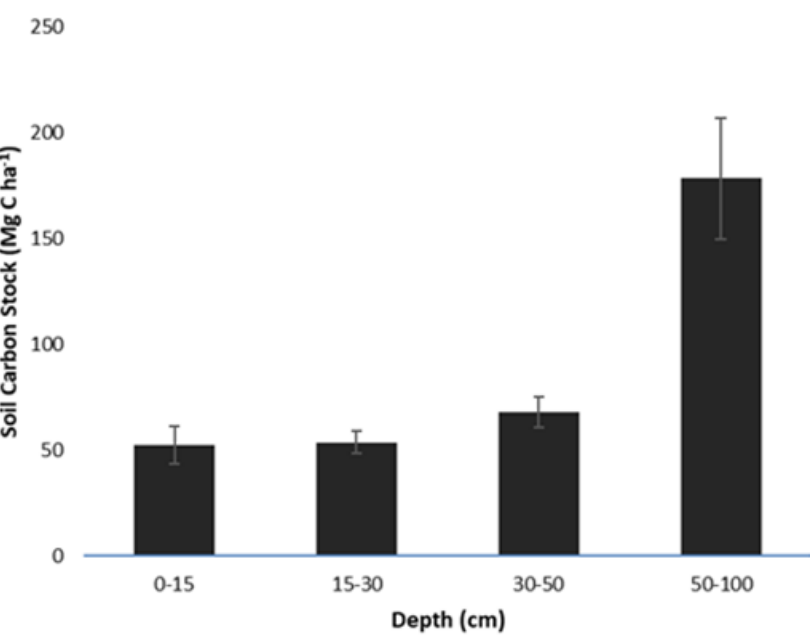

Figure 3. Soil carbon stock by sampling depth in Sulaman Lake Forest Reserved, Sabah, Malaysia

Figure 3 shows the trend of soil carbon stock by its sampling depth. The highest value was found in the depth of $50-100 \mathrm{~cm}$ which is $178.37 \pm 28.56 \mathrm{Mg} \mathrm{C} \mathrm{ha}^{-1}$ and there is a big gap between $50-100 \mathrm{~cm}$ depth with the other which is $52.12 \pm 8.90 \mathrm{Mg} \mathrm{C}^{-1}(0-15 \mathrm{~cm}), 53.60 \pm 5.29 \mathrm{Mg} \mathrm{C}$ ha $^{-1}(15-30 \mathrm{~cm})$ and $67.89 \pm 7.22 \mathrm{Mg} \mathrm{C}^{-1}(30-50 \mathrm{~cm})$. Similar result was reported by Hemati et al. (2015) in their study which the soil organic carbon is increasing by depth but an opposite trend was reported by Hong et al. (2017) in which the surface layer of the soil has a greater value of organic carbon compared to the lower part of soil profile. These differences in findings may be influenced by the disturbance history, pattern of tidal inundation, forest age, sedimentation, and species composition (Sherman et al. 2003; Hemati et al. 2015; Hong et al. 2017).

This study shows that soil carbon stock made up almost $80 \%$ of the total carbon stock and this value is slightly higher than a study reported by Hong et al. (2017) at degraded mangrove forest in Peninsular Malaysia which is $60 \%$. The higher number in this study might be affected by the depth of the soil sample that has been taken which is 1 meter depth compared to the previous study ( 0.3 meters). However, these reports are in contrast with the study reported by Besar et al. (2020) on a natural tropical forest carbon stock value. Their study shows that soil made up only $13 \%$ of the total ecosystem carbon stock while the living trees hold the most carbon with $87 \%$. This supported all the other findings that highlighted the fact that mangrove soils hold more carbon than their trees and roots compared to the other major global forest domains such tropical forest, boreal forest, and temperate forest (Donato et al. 2011; Kauffman et al. 2011).

Other than storing most of its carbon in the soil, mangrove ecosystem also reported are the most carbondense forest in tropical regions. According to Kauffman and Donato (2012), the carbon storage of mangrove forest in the Asia-Pacific region is estimated around $1000 \mathrm{Mg} \mathrm{C}$ $\mathrm{ha}^{-1}$ meanwhile tropical forest shows a lower value which is $280 \mathrm{Mg} \mathrm{C} \mathrm{ha}^{-1}$. Other types of forest also reported has lower carbon storage compared to a mangrove forest which temperate forest with $210 \mathrm{MgCha}^{-1}$ and boreal forest is 380 $\mathrm{Mg} \mathrm{C} \mathrm{ha-1}$, thus emphasizing how important it is to gather more knowledge about ecosystem carbon stock in mangrove forest so it can be included and being prioritize in the efforts to mitigate the climate change. A study on the spatial distribution of soil carbon stock in mangrove forest was done in 2018 and the finding shows mangrove forest stored around 6.4 $\mathrm{PgC}$ on the top meter of its soil in 2000 but almost $75 \%$ of it (30-122 $\mathrm{TgC}$ ) was released in between 2000 and 2015 because of the reduction in mangrove forest area which mostly occurred in Indonesia, Malaysia and Myanmar (Sanderman et al. 2018). All these reductions and degradation on coastal wetland could lead to a major emission from mangrove forest and shifting the role from becoming net source of carbon sink into the biggest source of carbon released back to the atmosphere and ocean (Howard et al. 2017).

From all the results and discussion above, it shows that Sulaman Lake Forest Reserve has the capability to store an enormous amount of carbon, especially on its soil. The comparison between our study site with other studies in the undisturbed mangrove forest (Kuala Selangor Nature Park) also shows how human activity could influence its ability to store carbon. The high percentage of soil carbon stock compared to other locations such inland forest also illuminates the fact that mangrove forest is also just important as natural tropical forest and more study needs to be done inside. The implementation of climate change mitigation projects such as REDD+ is also highly required to keep the current carbon stocks value inside the forest. 
And the information shown in this study can be used as guideline for further conservation or any sustainable forest management in Sulaman Lake Forest Reserve.

In conclusion, the total carbon stock in mangrove forests at Sulaman Lake Forest Reserve, Sabah, Malaysia was $441.72 \mathrm{Mg} \mathrm{C} \mathrm{Ha}^{-1}$. The soils in the mangrove forest are the major contributor to the total ecosystem carbon stocks followed by the aboveground (living trees and dead trees) and the belowground (roots).

\section{ACKNOWLEDGEMENTS}

This study was funded by University Malaysia Sabah with research grant SBK 0227-STWN 2015. We would like to thank Sabah Forestry Department for giving us permission to do our research in the research area. We also would like to thank En. Suntung and family for their help during field sampling.

\section{REFERENCES}

Adame MF, Cherian S, Reef R, Stewart-Koster B. 2017.Mangrove roo biomass and the uncertainty of belowground carbon estimations. For Ecol Manag 403: 52-60. DOI: 10.1016/j.foreco.2017.08.016.

Alongi DM, Murdiyarso D, Fourqurean JW, Kauffman JB, Hutahaean A, Crooks S, Lovelock CE, Howard J, Herr D, Fortes M, Pidgeon E, Wagey T.2016. Indonesia's blue carbon: a globally significant and vulnerable sink for seagrass and mangrove carbon. Wetlands Ecol Manage 24 (1): 3-13. DOI: 10.1007/s11273-015-9446-y.

Alongi DM, Dixon P.2000. Mangrove primary production and above-and below-ground biomass in Sawi Bay, Southern Thailand. Phuket Marine Biol Center Spec Publ 22: 31-38.

Besar NA, Suardi H, Phua MH, James D, Mokhtar M, Ahmed MF. 2020. Carbon Stock and Sequestration Potential of an Agroforestry System in Sabah, Carbon Stock and Sequestration Potential of an Agroforestry System in Sabah, Malaysia. Forests 11 (2): 210. DOI: 10.3390/f11020210.

Byran-Brown DN, Connolly RM, Richards DR, Adame F, Friess DA, Brown CJ. 2020. Global trends in mangrove forest fragmentation. Sci Rep 10 (1): 1-8. DOI: 10.1038/s41598-020-63880-1.

Chandra IA, Seca G, Abu Hena MK. 2011. Aboveground biomass production of Rhizophora apiculata Blume in Sarawak mangrove forest. Am J Agric Biol Sci 6 (4): 469-474. DOI: 10.3844/ajabssp.2011.469.474.

Chandra IA, Seca G, Noraini R, Ahmad MMP, Osumanu HA, Hazandy AH, Nik MAM. 2015. Soil carbon storage in dominant species of Mangrove Forest of Sarawak, Malaysia. Intl J Phys Sci 10 (6): 210 214. DOI: 10.5897/ijps2014.4183.

Clough BF, Scott K. 1989. Allometric relationships for estimating aboveground biomass in six mangroves species. For Ecol Manag 27: 117 127.

Culman S, Mann M, Brown C. 2019. Calculating Cation Exchange Capacity, Base Saturation, and Calcium Saturation. Agriculture and Natural Resources ANR-81: 6. https://ohioline.osu.edu/factsheet/anr81.

Dimalen FK, Rojo MJA. 2019. Carbon stock assessment of a mangrove forest in Cotabato City, Philippines. J Biodiv Environ Sci 14 (2): 1-8.

Donato DC, Kauffman JB, Murdiyarso D, Kurnianto S, Stidham M. 2011. Mangroves among the most carbon-rich forests in the tropics. Nature Geoscience 4: 293-297. DOI: 10.1038/ngeo1123.

FAO. 2020. Global Forest Resources Assessment 2020: Main report. Rome. DOI: 10.4060/ca9825en.

Fromard F, Puig H, Mougin E, Marty G, Betoulle JL, Cadamuro L. 1998. Structure, above-ground biomass and dynamics of mangrove ecosystems: New data from French Guiana. Oecologia 115 (1-2): 39 53. DOI: $10.1007 / \mathrm{s} 004420050489$.

Giri C, Ochieng E, Tieszen LL, Zhu Z, Singh A, Loveland T, Masek J, Duke N. 2011. Status and distribution of mangrove forests of the world using earth observation satellite data. Global Ecol Biogeogr 20: 154-159. DOI: 10.1111/j.1466-8238.2010.00584.x.

Goessens A, Satyanarayana B, Stocken TVD, Zuniga MQ, Mohd-Lokman H, Sulong I, Dahdouh-Guebas F. 2014. Is Matang Mangrove Forest in Malaysia Sustainably Rejuvenating after More than a Century of Conservation and Harvesting Management?. PloS ONE 9 (8). DOI: 10.1371/journal.pone.0105069.

Han Y, Zhang J, Mattson KG, Zhang W, Weber TA. 2016. Sample Sizes to Control Error Estimates in Determining Soil Bulk Density in California Forest Soils. Soil Sci Soc Am J 80 (3): 756-764. DOI: 10.2136/sssaj2015.12.0422.

Hance J. 2011. Vanishing mangroves are carbon sequestration powerhouse.

https://news.mongabay.com/2011/04/vanishing-mangroves-arecarbon-sequestration-powerhouses/

Hemati ZH, Mahmood H, Rozainah MZ. 2014. Biodiversity and biomass of a natural and degraded mangrove forest of Peninsular Malaysia. Environ Earth Sci 71 (11): 4629-4635. DOI: 10.1007/s12665-0132853-6.

Hemati Z, Hossain M, Emenike CU, Rozainah MZ. 2015. Rate of carbon storage in soil of natural and degraded mangrove forest in Peninsular Malaysia. Clean-Soil Air Water 43 (4): 614-619. DOI: 10.1002/clen.201400034.

Hong LC, Hemati ZH, Zakaria RM. 2017. Carbon stock evaluation of selected mangrove forests in peninsular Malaysia and its potential market value. J Environ Sci Manag 20 (2): 77-87.

Hossain MD, Nuruddin AA. 2016. Soil and mangrove: A review. J Environ Sci Technol 9 (2): 198-207. DOI: 10.3923/jest.2016.198.207

Hossain M, Othman S, Bujang JS, Kusnan M. 2008. Net primary productivity of Bruguiera parviflora (Wight \& Arn.) dominated mangrove forest at Kuala Selangor, Malaysia. Forest Ecol Manag 255 (1): 179-182. DOI: 10.1016/j.foreco.2007.09.011.

Houghton RA, Hackler JL. 2001. Carbon Flux to the Atmosphere from Land-Use Changes : 1850 to 1990. Environmental Sciences Division; Office of Biological and Environmental Research U.S. Department of Energy. USA. DOI: 10.3334/CDIAC/lue.ndp050.

Howard J, Sutton-Grier A, Herr D, Kleypas J, Landis E, Mcleod E, Pidgeon E, Simpson S. 2017. Clarifying the role of coastal and marine systems in climate mitigation. Front Ecol Environ 15 (1): 42-50. DOI: 10.1002/fee.1451.

Kanniah KD, Sheikhi A, Cracknell AP, Goh HC, Tan KP, Ho CS, Rasli FN. 2015. Satellite images for monitoring mangrove cover changes in a fast-growing economic region in southern Peninsular Malaysia. Rem Sens 7 (11): 14360-14385. DOI: 10.3390/rs71114360

Kauffman JB, Heider C, Cole TG, Dwire KA, Donato DC. 2011. Ecosystem carbon stocks of Micronesian mangrove forests. Wetlands 31 (2): 343-352. DOI: 10.1007/s13157-011-0148-9.

Kauffman JB, Donato D. 2012. Protocols for the measurement, monitoring and reporting of structure, biomass and carbon stocks in mangrove forests. Working Paper 86. CIFOR, Bogor, Indonesia. DOI: $10.17528 /$ cifor/003749.

Komiyama A, Havanond S, Srisawantt W, Mochida Y, Fujimoto K, Ohnishi T, Ishihara S, Miyagi T. 2000. Top/root biomass ratio of a secondary mangrove forest. For Ecol Manag 139: 127-134.

Komiyama A, Ong JE, Poungparn S. 2008. Allometry, biomass, and productivity of mangrove forests: A review. Aquatic Bot 89: 128-137. DOI: 10.1016/j.aquabot.2007.12.006.

Komiyama A, Poungparn S, Kato S. 2005. Common allometric equations for estimating the tree weight of mangroves. J Trop Ecol 21 (4): 471477. DOI: $10.1017 /$ S0266467405002476.

Kusmana C, Hidayat T, Tiryana T, Rusdiana O, Istomo. 2018. Allometric models for above-and below-ground biomass of Sonneratia spp. Global Ecol Conserv 15: e00417. DOI: 10.1016/j.gecco.2018.e00417.

Martuti NKT, Setyowati DL, Nugraha SB, Mutiatari DP. 2017. Carbon stock potency of mangrove ecosystem at Tapak Sub-village, Semarang, Indonesia. AACL Bioflux 10 (6): 1524-1533.

Marzuki FH. 2019. Keunikan Hutan Paya Bakau Malaysia. Forestry. https://www.forestry.gov.my/images/keratan_akhbar/2019/July/KOS MO14OGOS2019.pdf [Malaysian]

Njana MA, Eid T, Zahabu E, Malimbwi R. 2015. Procedures for quantification of belowground biomass of three mangrove tree species. Wetlands Ecol Manag 23 (4): 749-764. DOI: 10.1007/s11273-015-9417-3.

Olaniyi AO, Abdullah AM, Ramli MF, Alias MS. 2012. Assessment of drivers of coastal land-use change in Malaysia. Ocean Coast Manag 67: 113-123. DOI: 10.1016/j.ocecoaman.2012.05.029. 
Ong JE, Gong WK, Wong CH. 2004. Allometry and partitioning of the mangrove, Rhizophora apiculata. For Ecol Manag 188: 395-408.

Pearson TRH, Brown SL, Birdsey RA. 2007. Measurement Guidelines for the Sequestration of Forest Carbon. In General Technical Report NRS-18. Delaware: United States Department of Agriculture-Forest Service. Northern Research Station (42p). DOI: 10.2737/NRS-GTR18.

Rambok E, Gandaseca S, Ahmed OH, Muhamad N, Majid A. 2010 Comparison of Selected Soil Chemical Properties of Two Different Mangrove Forests in Sarawak. Am J Environ Sci 6 (5): 438-441.

Rizal A, Sahidin A, Herawati H. 2018. Economic Value Estimation of Mangrove Ecosystems in Indonesia. Biodiv Intl J 2 (1): 98-100. DOI: 10.15406/bij.2018.02.00051.

Sanderman J, Hengl T, Fiske G, Solvik K, Adame MF, Benson L, Bukoski JJ, Carnell P, Cifuentes-Jara M, Nonato D, Duncan C, Eid EM, Ermgassen PZ, Lewis CJE, Macreadiw PI, Glass L, Gress S, Jardine SL, Jones TG, Nsombo EN, Rahman MM, Sanders CJ, Spalding M, Landis E. 2018. A global map of mangrove forest soil carbon at $30 \mathrm{~m}$ spatial resolution. Environ Res Lett 13 (5). DOI: 10.1088/1748-9326/aabe1c

Sherman RE, Fahey TJ, Martinez P. 2003. Spatial Patterns of Biomass and Aboveground Net Primary Productivity in a Mangrove Ecosystem in the Dominican Republic. Ecosystems 6 (4): 384-398. DOI:10.1007/s10021-002-0191-8.

Shukla A, Panchal H, Mishra M, Patel PR, Srivastava HS, Patel P, Shukla AK. 2014. Soil Moisture Estimation using Gravimetric Technique and FDR Probe Technique : A Comparative Analysis. American Intl J Res Formal Appl Nat Sci 8 (1): 89-92.

Tangah J, Chung AYC. 2011. The Challenges of Mangrove Forest Conservation and Rehabilitation in Sabah, Malaysia. Asian Wetland Symposium (AWS) in Integrated Biodiversity Conservation: Linking Forests and Wetlands, (July), 1-13.

Tangah J, Chung AYC, Baba S, Chan HT, Kezuka M. 2020. Rehabilitation of Mangroves in Sabah: The SFD-ISME Collaboration (2014-2019). Sabah Forestry Department, International Society for Mangrove Ecosystems and Tokio Marine and Nichido Fire Insurance Co. Ltd., Malaysia.

Wong CJ, James D, Besar NA, Kamlun KU, Tangah J, Tsuyuki S, Phua MH. 2020. Estimating Mangrove Above-Ground Biomass Loss Due to Deforestation in Malaysian Northern Borneo between 2000 and 2015 Using SRTM and Landsat Images. Forests 11 (9): 1018. DOI: $10.3390 / \mathrm{f} 11091018$ 